\title{
Prevalence, Patterns and Associated Factors of Injuries in School-aged Cameroonian Children
}

\author{
Christelle Senterre $^{1, *}$, Alain Levêque ${ }^{1}$, Michèle Dramaix ${ }^{1}$, Danielle Piette $^{2}$ \\ ${ }^{1}$ Research Centre of Epidemiology, Biostatistics and Clinical Research, School of Public Health, \\ Université Libre de Bruxelles, Brussels, Belgium \\ ${ }^{2}$ Research Centre of Social Approaches to Health, School of Public Health, Université Libre de Bruxelles, Brussels, Belgium \\ *Corresponding Author: Christelle.Senterre@ulb.ac.be
}

Copyright $@ 2014$ Horizon Research Publishing All rights reserved.

\begin{abstract}
Few studies have addressed the patterns of injuries in Africa, and most of them were based on hospital data. The objectives of this study were to describe, on the basis of the "First Survey Health Young People" performed in 2008 in Cameroon, the prevalence and the patterns of injuries and to investigate the relationship between these injuries and some health behaviors. The dataset included 47327 pupils, aged 9 to 25 years, with a sex-ratio close to one. The prevalence of reported injuries during the past 12 months was $50.8 \%$ for boys and $42.1 \%$ for girls. Most injuries occurred at home for girls (43.6\%) and during sports for boys $(22.5 \%)$. Multivariable models, by gender, showed that age, alcohol consumption, exercise performed during free time, feelings about school, truancy, happiness, feeling alone, number of close friends, feeling of kindness and helpfulness of the other pupils, possibility to talk with parents or tutors, perception about one's own health, feeling tired on the morning of schooldays and some violent behaviors (fights, racket events and number of times students reported taking a weapon at school) were all associated with the occurrence of injuries. These results increase the knowledge of the epidemiology of injuries in Africa (in terms of morbidity and associated factors) and should lead to an integrated approach of the health behaviors in injury prevention.
\end{abstract}

Keywords Injuries, Injury prevention, Youth, Health Behaviors, School health, Epidemiology, Cameroon

\section{Introduction}

In its World Report on Child Injury Prevention, the World Health Organization (WHO) [1] wrote that "childhood injury is a major public health problem that requires urgent attention. Injury and violence is a major killer of children throughout the world [...]. The burden of injury on children falls unequally. It is heaviest among the poor with the burden greatest on children in the poorer countries with lower incomes". In their paper on the growing burden of trauma and injury in low and middle income countries, Hofman, Primack, Keisch and Hrynkow [2] have reported that almost $90 \%$ of deaths due to injuries occur in low and middle income countries, and this situation will continue to represent an important global health problem in the upcoming years. If in industrial countries, death from all form of unintentional injury has decreased significantly, in Africa, there is a dramatic increase in death from these types of injuries [3]. Injury related mortality rates in sub-Saharan Africa are among the highest in the world and according to the WHO, Cameroon has an estimated annual mortality rate due to injury of nearly 102 per 100,000 individuals [4]. Moreover, mortality is sometimes described - as Howe, Huttly and Abramsky [5] said, as"the "tip of the iceberg", because for every child who dies many more will suffer non-fatal injuries" and "a proportion of these will be left with varying degrees of disability". So, next to this high mortality fairly well documented, there is also a significant morbidity for which there is a lack of information [3, 5-8].

Furthermore, information regarding the epidemiology of injury in Africa is sparse and availability of data on children and young people are extremely limited $[4,5,8]$. Moreover, the majority of these studies were usually based on hospital data; such data may provide information on the type and severity of injuries, but they contain little information on associated factors; yet, this information is important to implement appropriate prevention interventions $[3,4,6$, 8-12]. Data based on population surveys, which can provide more information on associated factors, are rare - especially for young people - but are very important because they can provide patterns of injury and demonstrate the existence of variations in health profiles from childhood, through early adolescence, to young adulthood $[11,14,15]$. Finally, these data can help to identify the injuries that were not medically treated because it is known that even "small accidents" carry information towards a better prevention[1, 17, 18].

Based on the "First Survey Health Young People" which was performed at the end of 2008 in Cameroon, the objectives of this study were, first, to describe the prevalence 
and patterns of injuries in terms of place and activity and, secondly, to investigate the relationship between these injuries and some health behaviors reported by the young people included in the survey to identify the risk factors associated.

\section{Materials and Methods}

\subsection{Context, Study Population and Design, and Data Collection}

This article is based on a secondary analysis of the cross-sectional study "First Survey Health of Young People". This study was conducted within the framework of the "Implementation of a School Health Policy" at the request of the Ministry of Education in Cameroon, to collect health information in a representative sample of schoolchildren and students [19]. All young people included in this study were between 9 and 25 years old and attended primary or secondary education. Younger children were not included because experience has shown that it is hard for them to complete a questionnaire; accordingly, most international studies - like the "Health behavior in School-aged Children" study(HBSC) generally do not consider children under 10 years in their protocols[20].

Primary school is compulsory in Cameroon. In 2004, school attendance was just below $90 \%$ for boys between 8 and 14 years old and around $80 \%$ in girls. At 18 years, it was $60 \%$ and $38 \%$, respectively [21]

The sample size was based on a precision of $3 \%$ around a proportion of $50 \%$, a confidence interval of $95 \%$ and a design effect equal to 1.2 (based on the 1994/1995 and 1997/1998 HBSC Studies). Taking also account of the 4 socio-climate zones, the 10 regions and the 2 cities of Yaoundé and Douala, a large sample of 62000 young people was expected with school classes as primary sample units. The sample was expected to be representative for the country's regions, provinces, educational networks, types of education, French or English languages, levels of education and gender.

A self-administered questionnaire was used. It was largely inspired from the 2006 HBSC survey and was adapted to the Cameroonian context (with the help and the agreement of school doctors and experts from the Ministries of Health and Education). The filling of the questionnaire was done between October and November 2008, and data were encoded between December 2008 and February 2009.The final dataset received for the present analyses contained questionnaires from 47327 students, corresponding to a response rate equal to $76 \%$.

\subsection{Variables}

\subsubsection{Main Outcome}

The purpose of our analyses was to describe the epidemiology of injuries in the surveyed group.
Before asking information about the past injuries, there were sentences that explain what were considered as "injury" (or "accident"): "Many young people get hurt or are injured from activities such as playing sports or fighting with others, or when they work or on the way to school, to their home, when they are in the street or elsewhere. Injuries or accidents can include being burned or intoxicated. Injuries do not include illnesses such as measles or the flu. The following questions are about injuries you may have had during the past 12 months."

The main outcome consisted of the responses to having been injured the dependent variable was based on the dichotomization of the response possibilities to the question "During the past 12 months, have you been injured (i.e. an open wound, a large bruise)?". The response "I was not injured in the past 12 months" was chosen to indicate "absence of injury"; whereas all the positive responses ("I have been injured once", "... twice" and "... three or more times") were grouped into a single category of "past injury". Since youngsters may have had more than one injury during the past 12 months, the questions about the place, the activity at the moment of injury, the number of school days missed and the treatment were related to the most serious injury (the sentence: "Think only about the most serious injury that you had within the last 12 months" was mentioned before these questions).

\subsubsection{Independent Variables}

The seventeen independent variables that were considered were sex, age, tobacco and alcohol consumption, exercise performed during free time, feelings about school, truancy, happiness, feeling alone, number of close friends, feeling of kindness and helpfulness by the other pupils, possibility to talk with parents or tutors, perception about one's own health [self-perceived health], feeling tired on the morning of schooldays, fights with others, number of times students reported taking a weapon at school and racket events.

\subsection{Statistical Analyses}

Percentages were used to report all variables except for the number of school days missed, which is reported as median (P25-P75). For the description of the characteristics of the youngsters, we kept all the categories of the independent variables, but for the study of injuries, we grouped some categories to ensure a sufficient number of subjects in each of them. Before the grouping, we verified that the prevalence of injuries was nearly the same in the regrouped categories. The relationships between injuries and all independent variables were assessed using Pearson's chi-square test.

When the proportions of injuries increased (or decreased) in ordered categories of the independent variables, we applied the Cochran-Armitage test for trend. Results were considered statistically significant when $\mathrm{p}<0.05$. We also calculated odds ratios(OR) with confidence intervals $(95 \% \mathrm{CI})$ to estimate the strengths of the associations. To highlight the "at risk" categories of independent variables 
$(\mathrm{OR}>1)$, we chose the category with the lowest prevalence of injuries as reference $(\mathrm{OR}=1)$. To further assess these relationships, a logistic regression model was applied.

Because of the differences observed in univariate analyses between boys and girls, we tested, with a likelihood ratio test, the interactions between some independent variables (exercise performed during free time, feelings about school, happiness, feeling lonely, self-perceived health) and gender. Since the interaction terms with gender were significant $(\mathrm{p}=$ 0.0174 ), we presented the models separately by gender. Adjusted odds ratios, derived from the final models, were presented with their $95 \%$ confidence intervals and the p-value of the Wald's test, and to assess the fit of each models, we used the Hosmer and Leme show goodness-of-fit test [22].

\section{Results}

\subsection{Characteristics of the Study Population}

The sex ratio was close to one, and half the pupils were between 12 and 15 years. The majority (92.3\%) had never smoked, with a greater proportion for girls than boys $(96.5 \%$ vs. $88.4 \%$ ); a little more than one-fifth (22.6\%) had already been drunk once or more, with a lower proportion for girls than boys $(16.9 \%$ vs. $27.8 \%, \mathrm{p}<0.001)$.Less than a tenth $(8.9 \%)$ did not exercise outside school hours, with a greater proportion for girls than boys $(10.9 \%$ vs. $7.0 \%)$ (Table 1$)$.

Table 2 shows that a little more than half the students (56.5\%) appreciated school a lot and that boys were more likely to dislike school than girls $(6.2 \%$ for boys vs. $3.7 \%$ for girls). A large part of the youngsters (85.2\%) reported never to have been absent from school, for anything other than illness, since the beginning of the school year, the proportion being higher for girls than boys ( $89.0 \%$ vs. $81.7 \%)$. Overall, most students $(62.8 \%)$ were (very) happy with a small difference in favor of girls (33.5\% of "very happy" vs. 30.5\% for boys), and three-quarters (75.8\%) felt never or sometimes lonely, the proportion being greater for boys $(37.5 \%$ vs.33.9\%). Two-thirds (67.0\%) reported having two or more close friends and this proportion was higher in boys $(72.6 \%$ vs. $61.3 \%$ for girls). Half the respondents $(52.0 \%)$ reported that the other pupils were always or often kind and helpful with them, and most children could always or often (38.0\%) talk with adults (parents or tutors) about leisure time, activities outside school, but also about problems and what was troubling them. Finally, approximately two-thirds $(65.4 \%)$ of the young people replied to be in rather good or excellent health, but less so among girls $(62.1 \%)$ than boys (.68.5\%); almost nine out of ten (89.4\%) pupils reported being rarely or never tired when waking up in the morning to go to school, with a small difference to the disadvantage of boys ( $88.6 \%$ vs. $90.5 \%$ for girls).

Considering violence behavior, nearly one-third (30.3\%) of the respondents declared at least one fight within the last twelve months, the proportion being greater for boys than girls ( $34.5 \%$ vs. $25.7 \%$ ). Overall, the fights were mainly with brothers / sisters (25.1\%), close friends or friends (20.8\%) or intimate partners $(15.8 \%)$. Fights with close friends or friends were reported more by boys than girls $(24.6 \%$ vs. $15.0 \%$ ), whereas girls had more frequently fights with brothers or sisters $(17.9 \%$ vs. $36.2 \%)$. Boys also reported more fights with unknown people $(22.4 \%$ vs. $13.6 \%$ for girls).Three-quarters had no weapon, but $5 \%$ said that they had taken a weapon (knife, dagger, stones or broken glass) at least once to go to school, this being done by boys than girls $(6.2 \%$ vs. $3.7 \%)$. A little less than a quarter $(22.5 \%)$ had been bullied / racketed since the beginning of the school year, with a greater proportion among boys $(25.4 \%$ vs. $19.4 \%$ for girls)(Table 3).

Table 1. Gender, age and characteristics of tobacco, alcohol use and physical activity, for the total study population and according to gender.

\begin{tabular}{|c|c|c|c|}
\hline $\begin{array}{c}\text { Gender, age, tobacco and } \\
\text { alcohol use }\end{array}$ & $\begin{array}{c}\text { Total } \\
\%\end{array}$ & $\begin{array}{c}\text { Boys } \\
\%\end{array}$ & $\begin{array}{c}\text { Girls } \\
\%\end{array}$ \\
\hline $\begin{array}{l}\text { Gender } \\
\text { Male } \\
\text { Female }\end{array}$ & $\begin{array}{c}(\mathrm{n}=46568) \\
51.8 \\
48.2\end{array}$ & & \\
\hline $\begin{array}{c}\text { Age (Years) } \\
9-11 \\
12-13 \\
14-15 \\
16-17 \\
18-25\end{array}$ & $\begin{array}{c}(\mathrm{n}=44120) \\
12.3 \\
26.8 \\
23.4 \\
19.4 \\
24.4\end{array}$ & $\begin{array}{c}(\mathrm{n}= \\
22573) \\
11.4 \\
19.7 \\
23.3 \\
19.4 \\
26.3 \\
p\end{array}$ & $\begin{array}{c}(\mathrm{n}= \\
21105) \\
13.4 \\
21.4 \\
23.4 \\
19.4 \\
22.4 \\
1\end{array}$ \\
\hline $\begin{array}{c}\text { Tobacco } \\
\text { Never smoked } \\
\text { Have tried but don't } \\
\text { smoke now } \\
\text { Smoke, less than once a } \\
\text { week } \\
\text { Smoke, at least once a } \\
\text { week } \\
\text { Smoke everyday }\end{array}$ & $\begin{array}{c}(\mathrm{n}=46299) \\
92.3 \\
5.5 \\
1.0 \\
0.8 \\
0.4\end{array}$ & $\begin{array}{c}(\mathrm{n}= \\
23653) \\
88.4 \\
8.1 \\
1.5 \\
1.3 \\
0.7\end{array}$ & $\begin{array}{c}(\mathrm{n}= \\
22091) \\
96.5 \\
2.7 \\
0.4 \\
0.2 \\
0.2 \\
\end{array}$ \\
\hline $\begin{array}{c}\text { Alcohol } \\
\text { Never drink } \\
\text { Drink but never being } \\
\text { drunk } \\
\text { Having been drunk once } \\
\text { Having been drunk two or } \\
\text { three times } \\
\text { Being drunk between } 4 \\
\text { and } 10 \text { times } \\
\text { Being drunk more than } 10 \\
\text { times }\end{array}$ & $\begin{array}{c}(\mathrm{n}=45603) \\
38.9 \\
38.5 \\
15.1 \\
4.6 \\
1.0 \\
1.9\end{array}$ & $\begin{array}{c}(\mathrm{n}= \\
23227) \\
37.0 \\
35.2 \\
16.9 \\
6.4 \\
1.5 \\
3.0\end{array}$ & $\begin{array}{c}(\mathrm{n}= \\
21706) \\
40.9 \\
42.2 \\
13.3 \\
2.7 \\
0.3 \\
0.6\end{array}$ \\
\hline $\begin{array}{c}\text { Exercise during free time } \\
\text { Every day } \\
\text { Four to six times a week } \\
\text { Three times a week } \\
\text { Two times a week } \\
\text { Once a week } \\
\text { One to three times a } \\
\text { month } \\
\text { Less than once a month } \\
\text { Never }\end{array}$ & $\begin{array}{c}(\mathrm{n}=45339) \\
32.0 \\
10.5 \\
10.4 \\
14.3 \\
14.3 \\
5.0 \\
4.6 \\
8.9\end{array}$ & $\begin{array}{c}(\mathrm{n}= \\
23104) \\
33.5 \\
13.0 \\
11.8 \\
14.2 \\
11.9 \\
4.7 \\
3.9 \\
7.0 \\
\end{array}$ & $\begin{array}{c}(\mathrm{n}= \\
21523) \\
30.3 \\
7.9 \\
8.8 \\
14.4 \\
16.9 \\
5.2 \\
5.5 \\
10.9 \\
1\end{array}$ \\
\hline
\end{tabular}


Table 2. Characteristics of feelings and health perception, for all the study population and according to gender.

\begin{tabular}{|c|c|c|c|}
\hline $\begin{array}{c}\text { Feelings and health } \\
\text { perceptions }\end{array}$ & Total $\%$ & Boys \% & $\begin{array}{c}\text { Girls } \\
\%\end{array}$ \\
\hline $\begin{array}{c}\text { Feel about school } \\
\text { Like it a lot } \\
\text { Like it a bit } \\
\text { Don't like it very much } \\
\text { Don't like it at all }\end{array}$ & $\begin{array}{c}(\mathrm{n}=46330) \\
56.5 \\
38.5 \\
3.8 \\
1.2\end{array}$ & $\begin{array}{c}(\mathrm{n}=23552) \\
54.7 \\
39.1 \\
4.8 \\
1.4 \\
\\
\quad p\end{array}$ & $\begin{array}{c}(\mathrm{n}=22047) \\
58.6 \\
37.7 \\
2.8 \\
0.9 \\
001\end{array}$ \\
\hline $\begin{array}{c}\text { Truancy } \\
\text { Never } \\
\text { Yes, from time to time } \\
\text { Yes, one or several time } \\
\text { a month } \\
\text { Yes, at least once a } \\
\text { week }\end{array}$ & $\begin{array}{c}(\mathrm{n}=44039) \\
85.2 \\
7.8 \\
3.2 \\
3.8\end{array}$ & $\begin{array}{c}(\mathrm{n}=22377) \\
81.7 \\
9.7 \\
3.9 \\
4.7 \\
\\
\\
\quad p\end{array}$ & $\begin{array}{c}(\mathrm{n}=21000) \\
89.0 \\
5.7 \\
2.3 \\
3.0 \\
\\
\\
\end{array}$ \\
\hline $\begin{array}{c}\text { Feeling } \\
\text { Very happy } \\
\text { Happy } \\
\text { Don't feel very happy } \\
\text { Don't feel very happy at } \\
\text { all }\end{array}$ & $\begin{array}{c}(\mathrm{n}=45708) \\
31.9 \\
30.9 \\
26.9 \\
10.5\end{array}$ & $\begin{array}{c}(\mathrm{n}=23249) \\
30.5 \\
32.8 \\
26.3 \\
10.4 \\
\\
\quad p\end{array}$ & $\begin{array}{l}(\mathrm{n}=21757) \\
33.5 \\
28.9 \\
27.5 \\
10.0 \\
001\end{array}$ \\
\hline $\begin{array}{l}\text { Feeling lonely } \\
\text { Very often } \\
\text { Quite often } \\
\text { Sometimes } \\
\text { Never }\end{array}$ & $\begin{array}{c}(\mathrm{n}=46262) \\
18.0 \\
6.2 \\
40.0 \\
35.8\end{array}$ & $\begin{array}{c}(\mathrm{n}=23558) \\
17.4 \\
6.3 \\
38.9 \\
37.5 \\
\\
\quad p\end{array}$ & $\begin{array}{c}(\mathrm{n}=21995) \\
18.7 \\
6.1 \\
41.3 \\
33.9 \\
001\end{array}$ \\
\hline $\begin{array}{c}\text { Number of close friends } \\
\text { None } \\
\text { One } \\
\text { Two } \\
\text { Three or more }\end{array}$ & $\begin{array}{c}(\mathrm{n}=46116) \\
12.3 \\
20.7 \\
21.2 \\
45.8\end{array}$ & $\begin{array}{c}(\mathrm{n}=23464) \\
10.3 \\
17.1 \\
19.7 \\
52.9 \\
\quad p\end{array}$ & $\begin{array}{c}(\mathrm{n}=21926) \\
14.3 \\
24.4 \\
23.0 \\
38.3 \\
001\end{array}$ \\
\hline $\begin{array}{c}\text { Kindness and } \\
\text { helpfulness of pupils } \\
\text { Never } \\
\text { Rarely } \\
\text { Sometimes } \\
\text { Often } \\
\text { Always }\end{array}$ & $\begin{array}{c}(\mathrm{n}=46375) \\
7.4 \\
9.5 \\
31.1 \\
21.0 \\
31.0\end{array}$ & $\begin{array}{c}(\mathrm{n}=23586) \\
8.1 \\
9.5 \\
30.4 \\
21.1 \\
31.0 \\
\\
\quad p\end{array}$ & $\begin{array}{c}(\mathrm{n}=22062) \\
6.7 \\
9.5 \\
32.0 \\
20.9 \\
30.9 \\
001\end{array}$ \\
\hline $\begin{array}{c}\text { Talking to parents or } \\
\text { tutors } \\
\text { Never } \\
\text { Rarely } \\
\text { Sometimes } \\
\text { Often } \\
\text { Always }\end{array}$ & $\begin{array}{c}(\mathrm{n}= \\
45639) \\
28.2 \\
11.6 \\
22.2 \\
15.4 \\
22.6\end{array}$ & $\begin{array}{c}(\mathrm{n}=23230) \\
28.7 \\
11.8 \\
22.5 \\
15.5 \\
21.6 \\
\\
\end{array}$ & $\begin{array}{c}(\mathrm{n}=21717) \\
27.8 \\
11.4 \\
22.0 \\
15.3 \\
23.7 \\
001\end{array}$ \\
\hline $\begin{array}{c}\text { Perception of one's own } \\
\text { health } \\
\text { Excellent } \\
\text { Rather good } \\
\text { Neither good nor bad } \\
\text { Not so good } \\
\text { Poor, bad }\end{array}$ & $\begin{array}{c}(\mathrm{n}=45267) \\
38.7 \\
26.7 \\
16.6 \\
15.0 \\
3.0\end{array}$ & $\begin{array}{c}(\mathrm{n}=23052) \\
41.0 \\
27.5 \\
15.9 \\
12.9 \\
2.8 \\
\\
\end{array}$ & $\begin{array}{c}(\mathrm{n}=21516) \\
36.2 \\
25.9 \\
17.4 \\
17.3 \\
3.2 \\
001\end{array}$ \\
\hline
\end{tabular}

\begin{tabular}{|c|c|c|c|}
\hline Feeling tired on waking & & & \\
up & $(\mathrm{n}=45136)$ & $(\mathrm{n}=22975)$ & $(\mathrm{n}=21463)$ \\
Rarely or never & 48.6 & 48.2 & 49.0 \\
Sometimes & 40.8 & 40.4 & 41.5 \\
One to three times a & 6.4 & 6.7 & 6.0 \\
week & 4.1 & 4.7 & 3.5 \\
Four times or more a & & \multicolumn{2}{|c|}{$p<0.001$} \\
week & & \multicolumn{2}{|c|}{} \\
& &
\end{tabular}

Table 3. Characteristics of fights, taken weapons and of racket, for all the study population and according to gender.

\begin{tabular}{|c|c|c|c|}
\hline $\begin{array}{c}\text { Fights, taken weapons } \\
\text { and racket }\end{array}$ & $\begin{array}{c}\text { Total } \\
\% \\
\end{array}$ & $\begin{array}{c}\text { Boys } \\
\% \\
\end{array}$ & $\begin{array}{c}\text { Girls } \\
\%\end{array}$ \\
\hline $\begin{array}{c}\text { Fights } \\
\text { Never } \\
\text { Yes, one time } \\
\text { Yes, two times } \\
\text { Yes, three times } \\
\text { Yes, four times or more }\end{array}$ & $\begin{array}{c}(\mathrm{n}=45263) \\
69.7 \\
16.6 \\
5.4 \\
2.8 \\
5.5\end{array}$ & $\begin{array}{c}(\mathrm{n}=22999) \\
65.4 \\
17.8 \\
6.3 \\
3.4 \\
7.0 \\
\quad p<\end{array}$ & $\begin{array}{c}(\mathrm{n}=21573) \\
74.3 \\
15.4 \\
4.3 \\
2.1 \\
3.9 \\
01\end{array}$ \\
\hline $\begin{array}{c}\text { Fights against who? } \\
\text { Unknown people } \\
\text { Parents or adults from } \\
\text { family } \\
\text { Brothers or sisters } \\
\text { Girlfriend or boyfriend } \\
\text { Friend or knowing } \\
\text { people } \\
\text { Another person }\end{array}$ & $\begin{array}{c}(\mathrm{n}=12114) \\
18.9 \\
3.4 \\
25.1 \\
15.8 \\
20.8 \\
16.0\end{array}$ & $\begin{array}{c}(\mathrm{n}=7141) \\
22.4 \\
3.1 \\
17.9 \\
15.0 \\
24.6 \\
17.0 \\
\\
\\
\quad p<\end{array}$ & $\begin{array}{c}(\mathrm{n}=4794) \\
13.6 \\
3.7 \\
36.2 \\
17.2 \\
15.0 \\
14.3 \\
\end{array}$ \\
\hline $\begin{array}{l}\text { Taking a weapon at } \\
\text { school } \\
\text { Don't have } \\
\text { Don't bring } \\
\text { Yes, once } \\
\text { Yes, one or three times } \\
\text { Yes, four or five times } \\
\text { Yes, six times or more }\end{array}$ & $\begin{array}{c}(\mathrm{n}=45842) \\
74.6 \\
20.3 \\
2.9 \\
0.7 \\
0.5 \\
1.0\end{array}$ & $\begin{array}{c}(\mathrm{n}=23299) \\
75.2 \\
18.5 \\
3.4 \\
0.9 \\
0.5 \\
1.4 \\
\\
\quad p<\end{array}$ & $\begin{array}{c}(\mathrm{n}= \\
21826) \\
74.1 \\
22.2 \\
2.4 \\
0.5 \\
0.3 \\
0.5 \\
01\end{array}$ \\
\hline $\begin{array}{l}\text { Victim of racket } \\
\text { No } \\
\text { Yes, once } \\
\text { Yes, sometimes } \\
\text { Yes, often } \\
\text { Yes, very often }\end{array}$ & $\begin{array}{c}(\mathrm{n}=46058) \\
77.5 \\
12.9 \\
5.6 \\
1.9 \\
2.1\end{array}$ & $\begin{array}{c}(\mathrm{n}=23451) \\
74.6 \\
14.1 \\
6.5 \\
2.3 \\
2.5 \\
\\
\quad p<\end{array}$ & $\begin{array}{c}(\mathrm{n}= \\
21891) \\
80.6 \\
11.6 \\
4.7 \\
1.5 \\
1.6 \\
01\end{array}$ \\
\hline
\end{tabular}

\subsection{Characteristics of the Injuries}

Table 4 shows that approximately half $(46.7 \%)$ of the pupils reported having been injured at least once during the 12 months before the study, the proportion being higher among boys than girls (50.8\% vs. $42.1 \%)$.

Concerning the most serious injury, nearly one accident out of ten occurred in a street $(6.3 \%)$ or on the way to or from school (6.1\%) and two-third of injuries occurred at home $(34.5 \%)$, at a sport field (not belonging to the school) $(16.7 \%)$ or in the garden / the fields (14.4\%), with some gender and age group differences: girls were more injured at home 
( $43.6 \%$ vs. $27.6 \%$ for boys) while boys were more injured at a sport field (22.5\% vs. $9.1 \%$ for girls) and, on the one hand, the proportion of home injuries decreased with age increased, and on the other hand, injuries at sport fields increased with age (Figure 1\& Figure 2).

Table 4. Distribution of injuries, for all the study population and according to gender.

\begin{tabular}{|c|c|c|c|}
\hline Distribution of injuries & $\begin{array}{c}\text { Total } \\
\%\end{array}$ & $\begin{array}{c}\text { Boys } \\
\%\end{array}$ & $\begin{array}{c}\text { Girls } \\
\%\end{array}$ \\
\hline Injured during the past 12 & $(\mathrm{n}=45631)$ & $(\mathrm{n}=$ & $(\mathrm{n}=$ \\
months & 53.3 & $23267)$ & $21638)$ \\
Not injured & 29.7 & 49.2 & 57.9 \\
On time & 8.4 & 30.5 & 28.8 \\
Two times & 8.6 & 10.0 & 6.6 \\
Three times or more & & 10.3 & 6.7 \\
& & \multicolumn{2}{|c}{$p<0.001$} \\
\hline
\end{tabular}

Figure 3 shows the activity at the time of injury, for the study population and according to the gender. Less than ten percent of injuries resulted from driving as a driver or passenger of a motor bike or a motor vehicle $(4.8 \%$ and $2.7 \%$, respectively). Around a third was playing or training for sports $(30.8 \%)$, with a greater proportion for boys $(35.3 \% \mathrm{vs}$. $24.9 \%$ for girls), and another third was riding a bicycle or was walking / running - outside sports activities $(18.5 \%$ and $12.5 \%$ respectively), again with a gender difference: more bicycle activities for boys than girls $(23.1 \%$ vs. $13.6 \%)$ and more "walking / running" for girls (17.6\% vs. $8.7 \%$ for boys).

Slightly more than half $(53.4 \%, \mathrm{n}=18582)$ of the youngsters reported missing school at least one day because of their injury, with a median (P25-P75) number of school days missed of4 (2-7) $(n=7243)$. Absenteeism due to injury was higher for boys than girls $(54.6 \%$ versus $51.6 \% \%$ respectively, $\mathrm{p}<0.001, \mathrm{n}=18286)$, with a median ( $\mathrm{P} 25-\mathrm{P} 75)$ number of days missed of $4(2-10)$ for boys $(n=4200)$ and 3 (2-7) for girls $(n=2934)$. [Data not shown].

For the treatment of the injuries, several possibilities could be reported regarding the medical aspect, location and people involved. In a little less than a half of cases $(42.6 \%$, $\mathrm{n}=11131)$, the injury led to stay in a hospital at least one night, more so for girls $(46.2 \%, \mathrm{n}=4774)$ than boys $(39.6 \%$, $\mathrm{n}=6176, \mathrm{p}<0.001)$. Nearly two-fifths $(44.7 \%, \mathrm{n}=11093)$ reported having received stitches for their wounds, with no differences according to gender $(44.8 \%, \mathrm{n}=6411$ for boys and $44.4 \%$ for girls, $\mathrm{n}=4496 \mathrm{p}=0.696$ ); approximately a quarter $(27.3 \%, \mathrm{n}=14357)$ reported having needed a plaster cast, with a greater proportion for boys than girls $(28.6 \%, \mathrm{n}=$ 8197 vs. $25.3 \%, \mathrm{n}=5936$ for girls, $\mathrm{p}<0.001$ ) [Data not shown].Most frequently, treatment had been given by a doctor or a nurse in a hospital or in a health center $(68.0 \%)$ with some difference in favor of girls $(71.1 \%$ vs. $67.1 \%$ for boys), by parents or relatives $(64.4 \%)$ or at school by someone else (i.e. not by a doctor or a nurse). The treatments received elsewhere had been given by a quack, a priest or a marabout - corresponding to "informal care" - were also observed $(25.0 \%, 21.7 \%$ and $14.5 \%$ respectively), with little differences according to gender (Figure 4).

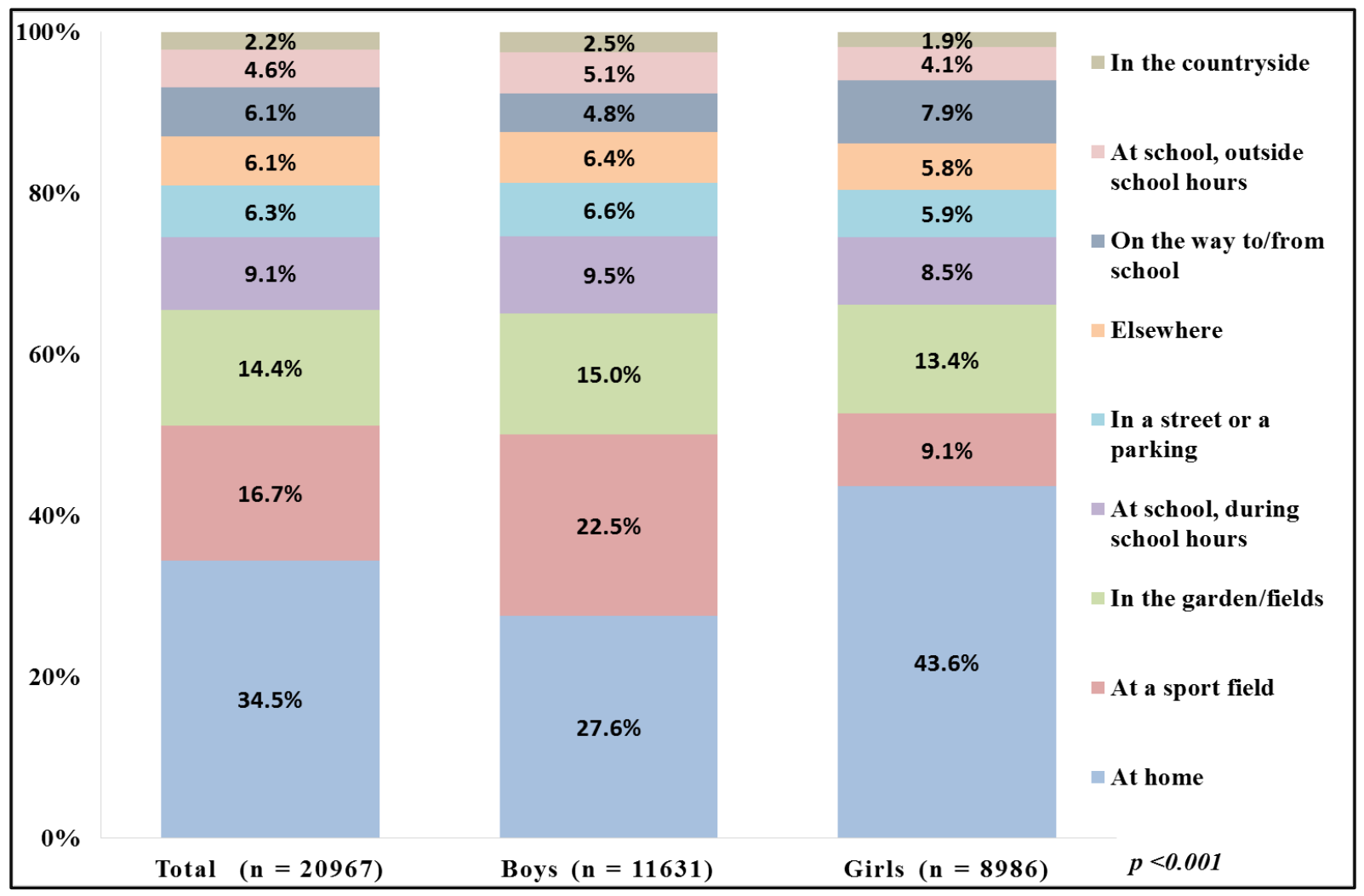

Figure 1. Place of injury's occurrences, for all the study population and according to gender. 


\begin{tabular}{|c|c|c|c|c|c|c|}
\hline \multirow[t]{3}{*}{$100 \%$} & $\begin{array}{l}1.5 \% \\
6.0 \%\end{array}$ & $\begin{array}{l}1.7 \% \\
5.5 \%\end{array}$ & $\begin{array}{l}1.9 \% \\
4.7 \%\end{array}$ & $\begin{array}{l}2.1 \% \\
3.9 \%\end{array}$ & $\begin{array}{l}3.9 \% \\
3.3 \%\end{array}$ & In the countryside \\
\hline & $5.8 \%$ & $5.6 \%$ & $6.2 \%$ & $6.2 \%$ & $6.6 \%$ & \\
\hline & $4.7 \%$ & $5.0 \%$ & $5.5 \%$ & $5.9 \%$ & & At school, outside \\
\hline \multirow[t]{2}{*}{$80 \%$} & $4.6 \%$ & $5.6 \%$ & $5.9 \%$ & $6.6 \%$ & 9.5\% & \\
\hline & $8.7 \%$ & $10.2 \%$ & $9.1 \%$ & $8.6 \%$ & $8.6 \%$ & $\begin{array}{l}\text { On the way to/from } \\
\text { school }\end{array}$ \\
\hline \multirow[t]{2}{*}{$60 \%$} & $13.7 \%$ & $14.4 \%$ & $14.1 \%$ & $14.7 \%$ & $7.5 \%$ & Elsewhere \\
\hline & $10.6 \%$ & & & & $14.7 \%$ & $\begin{array}{l}\text { In a street or a } \\
\text { parking }\end{array}$ \\
\hline $40 \%$ & & $14.8 \%$ & $17.7 \%$ & $18.6 \%$ & $20.1 \%$ & $\begin{array}{l}\text { At school, during } \\
\text { school hours }\end{array}$ \\
\hline $20 \%$ & $44.5 \%$ & $37.2 \%$ & $35.0 \%$ & $33.3 \%$ & & At a sport field \\
\hline $0 \%$ & $\begin{array}{l}9-11 \text { years } \\
(n=2685)\end{array}$ & $\begin{array}{c}12-13 \text { years } \\
(n=4404)\end{array}$ & $\begin{array}{c}14-15 \text { years } \\
(n=4724)\end{array}$ & $\begin{array}{c}16-17 \text { years } \\
(n=3647)\end{array}$ & $\begin{array}{c}\geq 18 \text { years } \\
(n=4011)\end{array}$ & $p<0.001$ \\
\hline
\end{tabular}

Figure 2. Place of injury's occurrences, for all the study population and according to age groups.

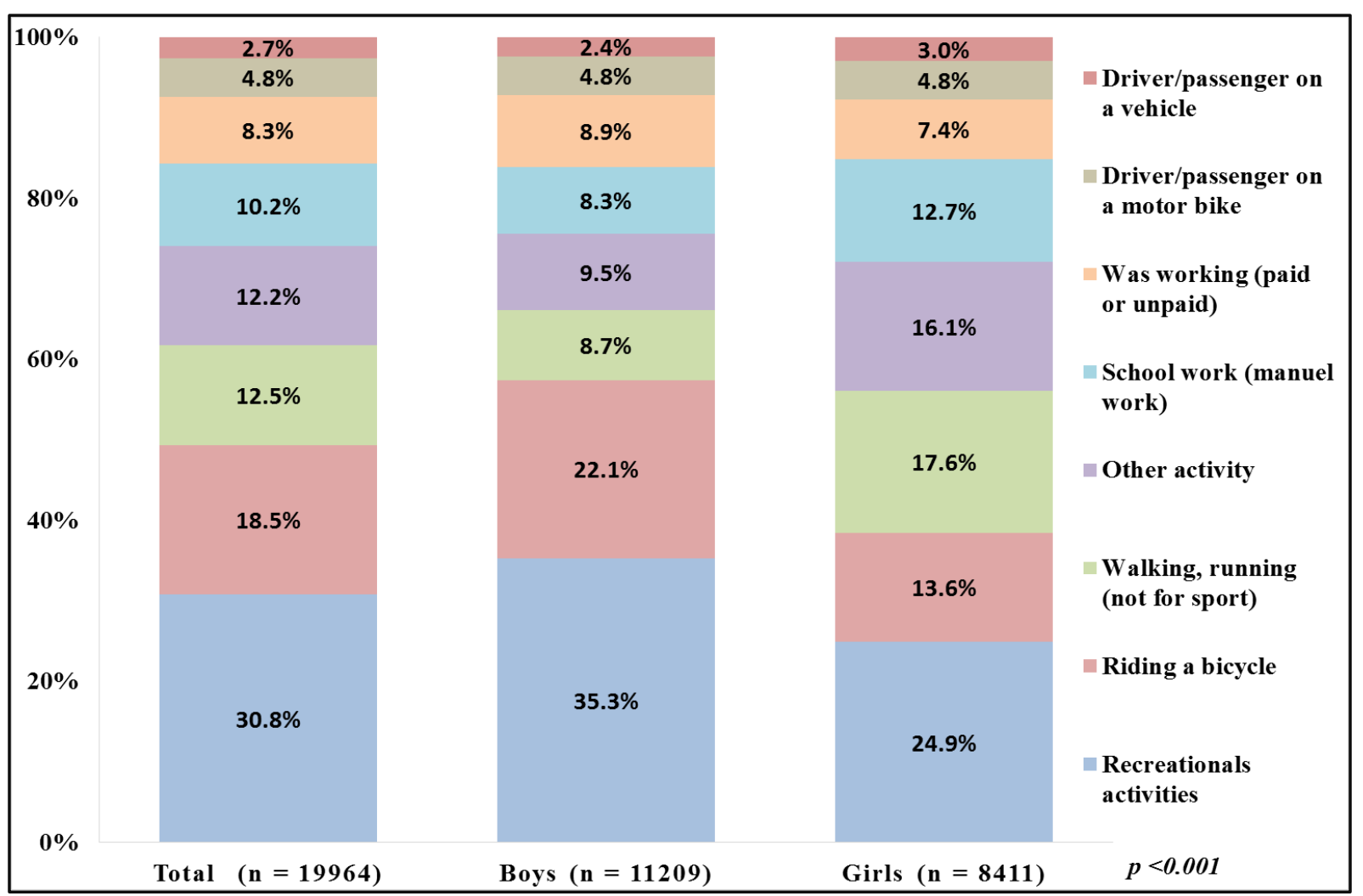

Figure 3. Activity at the moment of injuries, for all study population and according to the gender. 


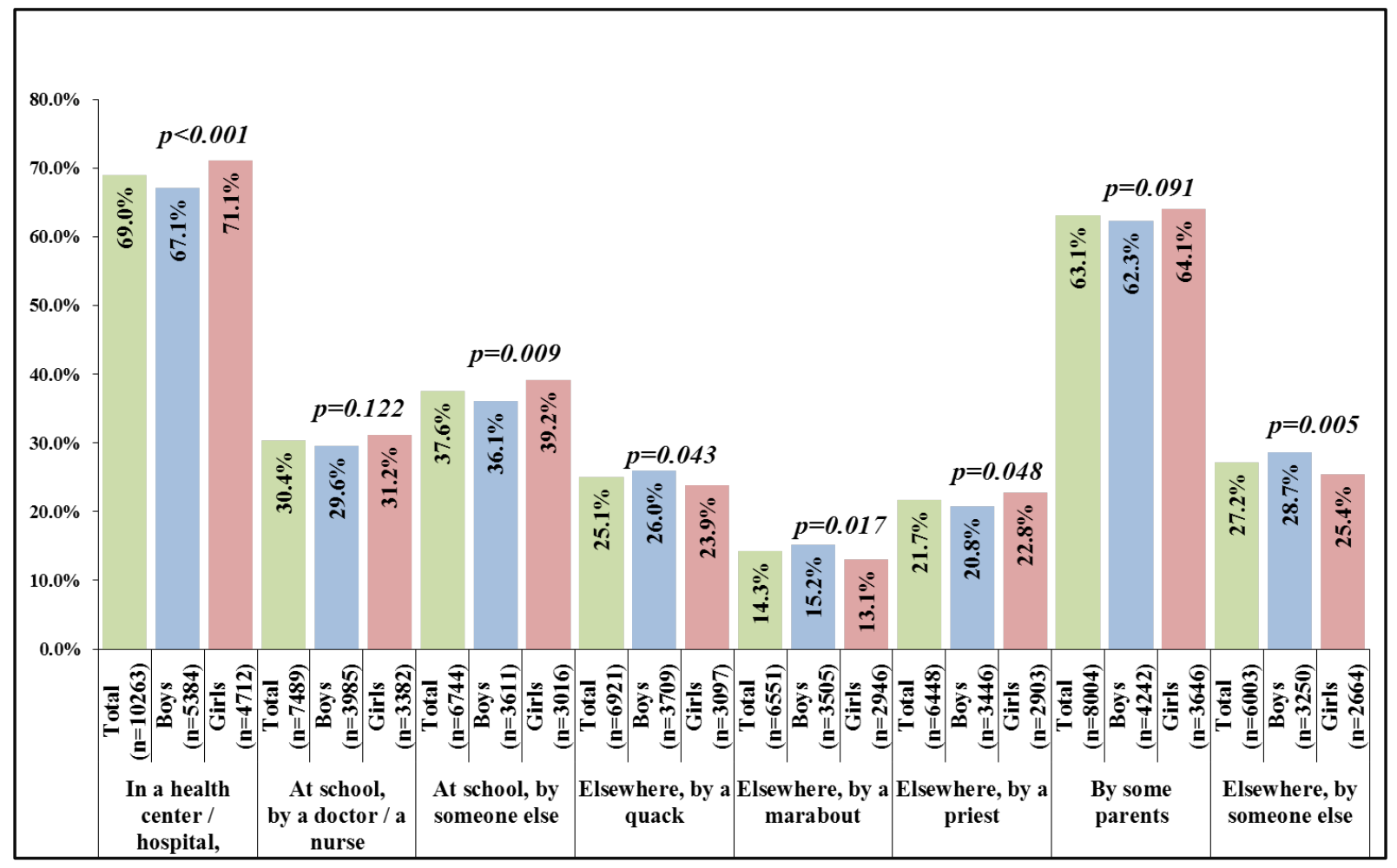

Figure 4. Injury's treatments, for all the study population and according to gender.

\subsection{Associations between Injuries and Independent Variables}

In univariate analyses, all independents variables were significantly associated with the occurrence of injuries, but some associations differed according to gender.

Table 4 had shown the higher proportion of injury for males. In table 5 , we could see the strength of the association regarding the odd ratio of injury for males (OR: 1.42vs. female, 95\%CI: 1.37-1.47). The prevalences of injuries were higher for smokers (1.4 vs. nonsmokers, 95\%CI: 1.29-1.66) and there were increasing linear trends of proportions of injuries when age decreased and when alcohol consumption increased, with similar situations for boys and girls. The prevalence of injuries increased with the prevalence of exercise during free time, but only for boys ( $p=0.013$ vs. $\mathrm{p}=0.252$ for girls) (Table 5).

Concerning the relationship with feelings and health perceptions, proportions of injuries were more prevalent among pupils reporting that they did not like very much or not at all going to school (OR: 1.21 vs. like it a lot or a bit, 95\%CI: 1.11-1.32), among those not feeling happy (OR: 1.08 vs. very happy or happy, 95\%CI: $1.04-1.12)$ - but these two associations were not significant for girls $(p=0.518$ and $\mathrm{p}=0.067$, respectively). Injuries were also more frequently reported by those feeling lonely very often or quite often (OR: 1.09 vs. sometimes or never, 95\% $\mathrm{CI}$ : 1.04-1.13), those finding themselves in not so good or bad health (OR: $1.07 \mathrm{vs}$. neither good nor bad, 95\%CI:1.01-1.15) - but these two associations were not significant for girls $(p=0.082$ and $p=0.067$, respectively); and those feeling tired in the morning once or more than once a week (OR: 1.41 vs. never, rarely or sometimes, 95\%CI:1.32-1.50).Results also showed significant linear increases in the proportions of injuries with the number of absences from school and according to the level of kindness and helpfulness by others pupils (but for the latter, there was no linear trend for girls).

Injuries were more frequent when students reported that they could talk sometimes or always with tutors or parents about leisure times and/or activities or problems (OR: 1.13 vs. never or rarely, 95\% IC: 1.09-1.18) and proportions of injuries decreased with a linear trend when the number of close friends increased (Table 6).

Finally, for both boys and girls, there was a linear increase in the prevalence of injuries with the frequencies of fights, racket events and the number of times students reported taking a weapon at school (Table 7). 
Table 5. Association between injuries and sex, age, tobacco and alcohol consumption, for all study population and according to gender

\begin{tabular}{|c|c|c|c|c|c|c|}
\hline \multirow[b]{2}{*}{ Sex, age, tobacco and alcohol use } & \multicolumn{2}{|c|}{ Total } & \multicolumn{2}{|c|}{ Boys } & \multicolumn{2}{|c|}{ Girls } \\
\hline & $\begin{array}{l}(\mathrm{n}) \\
\% \mathrm{I}^{+}\end{array}$ & $\begin{array}{c}\text { p-value \& } \\
\text { OR ( } 95 \% \text { IC) }\end{array}$ & $\begin{array}{l}(\mathrm{n}) \\
\% \mathrm{I}^{+}\end{array}$ & $\begin{array}{c}\text { p-value \& } \\
\text { OR (95\% IC) }\end{array}$ & $\begin{array}{l}(\mathrm{n}) \\
\% \mathrm{I}^{+}\end{array}$ & $\begin{array}{c}\text { p-value \& } \\
\text { OR }(95 \% \text { IC) }\end{array}$ \\
\hline Gender & $(n=23267)$ & & & & & \\
\hline Male & $\begin{array}{c}50.8 \\
(\mathrm{n}=21638)\end{array}$ & $1.42(1.37-1.47)$ & & & & \\
\hline Female & 42.1 & 1.00 & & & & \\
\hline Age (Years) & $(\mathrm{n}=5248)$ & $p<0.001^{*}$ & $(\mathrm{n}=2490)$ & $p<0.001$ & $(\mathrm{n}=2717)$ & $p<0.001^{*}$ \\
\hline $9-11$ & $\begin{array}{c}52.5 \\
(\mathrm{n}=8690)\end{array}$ & $1.74(1.63-1.86)$ & $\begin{array}{c}55.2 \\
(\mathrm{n}=4289)\end{array}$ & $1.55(1.41-1.71)$ & $\begin{array}{c}50.0 \\
(\mathrm{n}=4331)\end{array}$ & $2.11(1.92-2.33)$ \\
\hline $12-13$ & $\begin{array}{c}51.7 \\
(\mathrm{n}=9897)\end{array}$ & $1.68(1.59-1.78)$ & $\begin{array}{c}55.4 \\
(\mathrm{n}=5038)\end{array}$ & $1.57(1.45-1.70)$ & $\begin{array}{c}47.8 \\
(\mathrm{n}=4748)\end{array}$ & $1.94(1.78-2.11)$ \\
\hline $14-15$ & $\begin{array}{c}48.3 \\
(\mathrm{n}=8270)\end{array}$ & $1.47(1.39-1.55)$ & $\begin{array}{c}52.8 \\
(n=4223)\end{array}$ & $1.41(1.31-1.52)$ & $\begin{array}{c}43.5 \\
(n=3952)\end{array}$ & $1.62(1.49-1.77)$ \\
\hline $16-17$ & $\begin{array}{c}44.5 \\
(n=10438)\end{array}$ & $1.26(1.19-1.34)$ & $\begin{array}{c}50.0 \\
(\mathrm{n}=5739)\end{array}$ & $1.26(1.16-1.36)$ & $\begin{array}{c}38.7 \\
(\mathrm{n}=4589)\end{array}$ & $1.33(1.22-1.46)$ \\
\hline $18-25$ & 38.9 & 1.00 & 44.2 & 1.00 & 32.1 & 1.00 \\
\hline Tobacco & $(n=43650)$ & $p<0.001$ & $(n=22003)$ & $p=0.001$ & $(n=21120)$ & $p=0.013$ \\
\hline Never or try & $\begin{array}{c}46.5 \\
(n=999)\end{array}$ & 1.00 & $\begin{array}{c}50.7 \\
(\mathrm{n}=999)\end{array}$ & 1.00 & $\begin{array}{c}42.1 \\
(\mathrm{n}=177)\end{array}$ & 1.00 \\
\hline Smoker & 56.0 & $1.46(1.29-1.66)$ & 56.8 & $1.28(1.11-1.47)$ & 51.4 & $1.46(1.08-1.96)$ \\
\hline Alcohol & $(\mathrm{n}=34105)$ & $p<0.001^{*}$ & $(\mathrm{n}=16198)$ & $p<0.001$ & $(\mathrm{n}=17405)$ & $p<0.001^{*}$ \\
\hline Never or never being drunk & $\begin{array}{c}45.3 \\
(\mathrm{n}=8697)\end{array}$ & 1.00 & $\begin{array}{c}49.5 \\
(n=5220)\end{array}$ & 1.00 & $\begin{array}{c}41.4 \\
(n=3362)\end{array}$ & 1.00 \\
\hline Being drunk 1,2 or 3 times & $\begin{array}{c}51.3 \\
(\mathrm{n}=1260)\end{array}$ & $1.27(1.21-1.33)$ & $\begin{array}{c}54.7 \\
(\mathrm{n}=1035)\end{array}$ & $1.23(1.16-1.31)$ & $\begin{array}{c}46.0 \\
(n=194)\end{array}$ & $1.21(1.12-1.30)$ \\
\hline Being drunk 4 or more times & 51.6 & $1.28(1.15-1.44)$ & 52.3 & $1.12(0.99-1.27)$ & 46.4 & $1.23(0.92-1.63)$ \\
\hline Exercise during free time & $(n=23366)$ & $p<0.001^{*}$ & $(n=13111)$ & $p=0.013^{*}$ & $(\mathrm{n}=9862)$ & $p=0.252$ \\
\hline$\geq 3 \mathrm{x} /$ week & $\begin{array}{c}48.2 \\
(n=16829)\end{array}$ & $1.13(1.06-1.21)$ & $\begin{array}{c}52.0 \\
(\mathrm{n}=7807)\end{array}$ & $1.15(1.04-1.28)$ & $\begin{array}{c}43.0 \\
(\mathrm{n}=8781)\end{array}$ & $1.00(0.92-1.11)$ \\
\hline $2 \mathrm{x} /$ week to $>1 \mathrm{x} /$ month & $\begin{array}{c}46.1 \\
(\mathrm{n}=3897)\end{array}$ & $1.04(0.97-1.19)$ & $\begin{array}{c}50.8 \\
(\mathrm{n}=1576)\end{array}$ & $1.10(0.98-1.22)$ & $\begin{array}{c}41.8 \\
(\mathrm{n}=2261)\end{array}$ & $0.96(0.87-1.05)$ \\
\hline Never & 45.1 & 1.00 & 48.5 & 1.00 & 42.8 & 1.00 \\
\hline
\end{tabular}

(n) is the total number of subjects by categories, \% $\mathrm{I}^{+}$is the percentage of injuries and $*$ is a $\mathrm{p}$ value from a trend test

Table 6. Association between injuries and feelings and health perception, for all study population and according to gender

\begin{tabular}{|c|c|c|c|c|c|c|}
\hline \multirow[b]{2}{*}{ Feelings and health perceptions } & \multicolumn{2}{|c|}{ Total } & \multicolumn{2}{|c|}{ Boys } & \multicolumn{2}{|c|}{ Girls } \\
\hline & $\begin{array}{c}(\mathrm{n}) \\
\% \mathrm{I}^{+} \\
\end{array}$ & $\begin{array}{c}\text { p-value \& } \\
\text { OR (95\% IC) }\end{array}$ & $\begin{array}{l}(\mathrm{n}) \\
\% \mathrm{I}^{+} \\
\end{array}$ & $\begin{array}{c}\text { p-value \& } \\
\text { OR (95\% IC) }\end{array}$ & $\begin{array}{l}(\mathrm{n}) \\
\% \mathrm{I}^{+} \\
\end{array}$ & $\begin{array}{c}\text { p-value \& } \\
\text { OR }(95 \% \text { IC) }\end{array}$ \\
\hline Feel about school & $(n=42662)$ & $p<0.001$ & $(n=21437)$ & $p<0.001$ & $(\mathrm{n}=20563)$ & $p=0.518$ \\
\hline Like it a lot or a bit & $\begin{array}{c}46.6 \\
(\mathrm{n}=2244)\end{array}$ & 1.00 & $\begin{array}{c}50.7 \\
(\mathrm{n}=1417)\end{array}$ & 1.00 & $\begin{array}{c}42.2 \\
(\mathrm{n}=780)\end{array}$ & 1.00 \\
\hline Don't like very much or at all & 51.4 & $1.21(1.11-1.32)$ & 55.6 & $1.22(1.09-1.36)$ & 43.3 & $1.05(0.91-1.21)$ \\
\hline Truancy & $(n=36461)$ & $p<0.001^{*}$ & $(n=17790)$ & $p<0.001^{*}$ & $(\mathrm{n}=18155)$ & $p<0.001^{*}$ \\
\hline Never & $\begin{array}{c}45.1 \\
(\mathrm{n}=3343)\end{array}$ & 1.00 & $\begin{array}{c}49.2 \\
(\mathrm{n}=2116)\end{array}$ & 1.00 & $\begin{array}{c}40.9 \\
(\mathrm{n}=1161)\end{array}$ & 1.00 \\
\hline From time to time & $\begin{array}{c}52.8 \\
(\mathrm{n}=3009)\end{array}$ & $1.36(1.27-1.46)$ & $\begin{array}{c}56.5 \\
(\mathrm{n}=1873)\end{array}$ & $1.34(1.22-1.47)$ & $\begin{array}{c}45.9 \\
(\mathrm{n}=1074)\end{array}$ & $1.22(1.09-1.38)$ \\
\hline More than time to time & 56.0 & $1.55(1.44-1.67)$ & 58.5 & $1.45(1.32-1.60)$ & 51.7 & $1.54(1.36-1.75)$ \\
\hline Feeling & & $p<0.001$ & & $p<0.001$ & & $p=0.067$ \\
\hline Very happy or happy & $\begin{array}{c}46.1 \\
(n=16489)\end{array}$ & 1.00 & $\begin{array}{c}50.0 \\
(\mathrm{n}=8308)\end{array}$ & 1.00 & $\begin{array}{c}41.8 \\
(\mathrm{n}=7919)\end{array}$ & 1.00 \\
\hline Don't feel happy or at all & 48.1 & $1.08(1.04-1.12)$ & 52.9 & $1.12(1.07-1.19)$ & 43.1 & $1.05(0.99-1.12)$ \\
\hline Feeling lonely & $(\mathrm{n}=33872)$ & $p<0.001$ & $(n=17396)$ & $p<0.001$ & $(n=15961)$ & $p=0.082$ \\
\hline Sometimes or never & 46.2 & 1.00 & 50.1 & 1.00 & 41.9 & 1.00 \\
\hline
\end{tabular}




\begin{tabular}{|c|c|c|c|c|c|c|}
\hline Very often or quite often & $\begin{array}{c}(\mathrm{n}=10848) \\
48.3\end{array}$ & $1.09(1.04-1.13)$ & $\begin{array}{c}(\mathrm{n}=5389) \\
53.3\end{array}$ & $1.14(1.07-1.21)$ & $\begin{array}{c}(\mathrm{n}=5289) \\
43.2\end{array}$ & $1.06(0.99-1.13)$ \\
\hline Number of close friends & $(\mathrm{n}=5461)$ & $p<0.001^{*}$ & $(\mathrm{n}=2324)$ & $p<0.001^{*}$ & $(n=3033)$ & $p=0.001^{*}$ \\
\hline None & $\begin{array}{c}42.8 \\
(\mathrm{n}=18710)\end{array}$ & 1.00 & $\begin{array}{c}47.1 \\
(\mathrm{n}=8388)\end{array}$ & 1.00 & $\begin{array}{c}39.7 \\
(\mathrm{n}=10045)\end{array}$ & 1.00 \\
\hline One or two & $\begin{array}{c}45.7 \\
(n=20541)\end{array}$ & $1.12(1.05-1.19)$ & $\begin{array}{c}50.1 \\
(\mathrm{n}=12066)\end{array}$ & $1.13(1.03-1.24)$ & $\begin{array}{c}41.8 \\
(\mathrm{n}=8152)\end{array}$ & $1.09(1.00-1.18)$ \\
\hline Three or more & 48.9 & $1.28(1.20-1.36)$ & 52.4 & $1.24(1.13-1.35)$ & 43.6 & $1.17(1.08-1.28)$ \\
\hline Kindness and helpfulness of pupils & $(\mathrm{n}=7581)$ & $p<0.001 *$ & $(\mathrm{n}=4032)$ & $p<0.001^{*}$ & $(n=3433)$ & $p<0.001$ \\
\hline Never or rarely & $\begin{array}{c}50.3 \\
(\mathrm{n}=14033)\end{array}$ & $1.20(1.14-1.26)$ & $\begin{array}{c}53.7 \\
(\mathrm{n}=6941)\end{array}$ & $1.18(1.10-1.27)$ & $\begin{array}{c}46.5 \\
(\mathrm{n}=6852)\end{array}$ & $1.23(1.14-1.33)$ \\
\hline Sometimes & $\begin{array}{c}46.7 \\
(\mathrm{n}=23343)\end{array}$ & $1.04(0.99-1.08)$ & $\begin{array}{c}51.8 \\
(\mathrm{n}=11919)\end{array}$ & $1.09(1.03-1.16)$ & $\begin{array}{c}41.2 \\
(\mathrm{n}=23343)\end{array}$ & $0.99(0.93-1.05)$ \\
\hline Often or always & 45.8 & 1.00 & 49.6 & 1.00 & 41.5 & 1.00 \\
\hline Talking to parents or tutors & & $p<0.001$ & $(\mathrm{n}=14232)$ & $p<0.001$ & $(\mathrm{n}=12835)$ & $p<0.001$ \\
\hline Never or rarely & $\begin{array}{c}45.7 \\
(\mathrm{n}=16827)\end{array}$ & 1.00 & $\begin{array}{c}49.8 \\
(\mathrm{n}=8356)\end{array}$ & 1.00 & $\begin{array}{c}41.0 \\
(\mathrm{n}=8209)\end{array}$ & 1.00 \\
\hline Sometimes or always & 48.8 & $1.13(1.09-1.18)$ & 53.0 & $1.14(1.08-1.20)$ & 44.4 & $1.15(1.09-1.22)$ \\
\hline Perception of one's own health & $(\mathrm{n}=28732)$ & $p=0.023$ & $(n=15344)$ & $p<0.001$ & $(n=12937)$ & $p=0.067$ \\
\hline Excellent or rather good & $\begin{array}{c}46.5 \\
(\mathrm{n}=7328)\end{array}$ & $1.01(0.96-1.06)$ & $\begin{array}{c}50.1 \\
(\mathrm{n}=7328)\end{array}$ & $0.92(0.86-0.99)$ & $\begin{array}{c}42.3 \\
(\mathrm{n}=3627)\end{array}$ & $1.07(0.99-1.16)$ \\
\hline Nor good nor bad & $\begin{array}{c}46.3 \\
(\mathrm{n}=7937)\end{array}$ & 1.00 & $\begin{array}{c}52.1 \\
(\mathrm{n}=7937)\end{array}$ & 1.00 & $\begin{array}{c}405 \\
(\mathrm{n}=4321)\end{array}$ & 1.00 \\
\hline Not so good or poor, bad & 48.2 & $1.07(1.01-1.15)$ & 54.1 & $1.09(0.99-1.19)$ & 43.0 & $1.11(1.01-1.21)$ \\
\hline Feeling tired on waking up & $(\mathrm{n}=39225)$ & $p<0.001$ & $(n=19798)$ & $p<0.001$ & $(n=18844)$ & $p<0.001$ \\
\hline Never, rarely or sometimes & $\begin{array}{c}45.9 \\
(\mathrm{n}=4652)\end{array}$ & 1.00 & $\begin{array}{c}49.9 \\
(\mathrm{n}=2565)\end{array}$ & 1.00 & $\begin{array}{c}41.5 \\
(\mathrm{n}=1992)\end{array}$ & 1.00 \\
\hline One or more a week & 54.5 & $1.41(1.32-1.50)$ & 59.5 & $1.47(1.35-1.60)$ & 47.6 & $1.29(1.35-1.60)$ \\
\hline
\end{tabular}

(n) is the total number of subjects by categories, $\%$ I is the percentage of injuries and $*$ is a $p$ value from a trend test

Table 7. Association between injuries and feelings and health perception

\begin{tabular}{|c|c|c|c|c|c|c|}
\hline \multirow[b]{2}{*}{ Fights, taken weapons and racket } & \multicolumn{2}{|c|}{ Total } & \multicolumn{2}{|c|}{ Boys } & \multicolumn{2}{|c|}{ Girls } \\
\hline & $\begin{array}{c}(\mathrm{n}) \\
\% \mathrm{I}^{+} \\
\end{array}$ & $\begin{array}{c}\text { p-value \& } \\
\text { OR }(95 \% \text { IC) }\end{array}$ & $\begin{array}{c}(\mathrm{n}) \\
\% \mathrm{I}^{+} \\
\end{array}$ & $\begin{array}{c}\text { p-value \& } \\
\text { OR }(95 \% \text { IC) }\end{array}$ & $\begin{array}{c}(\mathrm{n}) \\
\% \mathrm{I}^{+} \\
\end{array}$ & $\begin{array}{c}\text { p-value \& } \\
\text { OR }(95 \% \text { IC) }\end{array}$ \\
\hline Fights & $(n=30612)$ & $p<0.001^{*}$ & $(n=14597)$ & $p<0.001^{*}$ & $(\mathrm{n}=15543)$ & $p<0.001^{*}$ \\
\hline Never & $\begin{array}{c}42.0 \\
(\mathrm{n}=9707)\end{array}$ & 1.00 & $\begin{array}{c}46.0 \\
(n=5427)\end{array}$ & 1.00 & $\begin{array}{c}38.2 \\
(\mathrm{n}=4129)\end{array}$ & 1.00 \\
\hline One or two times & $\begin{array}{c}56.0 \\
(\mathrm{n}=3659)\end{array}$ & $1.76(1.68-1.84)$ & $\begin{array}{c}58.5 \\
(\mathrm{n}=2356)\end{array}$ & $1.66(1.56-1.77)$ & $\begin{array}{c}52.5 \\
(\mathrm{n}=1254)\end{array}$ & $1.79(1.70-1.92)$ \\
\hline Three times or more & 62.8 & $2.33(2.17-2.50)$ & 65.2 & $2.20(2.01-2.41)$ & 58.5 & $2.28(2.01-2.41)$ \\
\hline Taking a weapon at school & $(\mathrm{n}=33510)$ & $p<0.001$ & $(n=17192)$ & $p<0.001$ & $(\mathrm{n}=15809)$ & $p<0.001$ \\
\hline Don't have & $\begin{array}{c}44.3 \\
(\mathrm{n}=9043)\end{array}$ & 1.00 & $\begin{array}{c}48.4 \\
(\mathrm{n}=4214)\end{array}$ & 1.00 & $\begin{array}{c}39.6 \\
(\mathrm{n}=4691)\end{array}$ & 1.00 \\
\hline Don't bring & $\begin{array}{c}51.4 \\
(\mathrm{n}=1624)\end{array}$ & $1.33(1.27-1.39)$ & $\begin{array}{c}55.3 \\
(\mathrm{n}=986)\end{array}$ & $1.32(1.23-1.41)$ & $\begin{array}{c}47.9 \\
(n=604)\end{array}$ & $1.41(1.32-1.50)$ \\
\hline Yes, one or three times & $\begin{array}{c}67.8 \\
(\mathrm{n}=661)\end{array}$ & $2.65(2.38-2.95)$ & $\begin{array}{c}70.5 \\
(\mathrm{n}=442)\end{array}$ & $2.54(2.12-2.93)$ & $\begin{array}{c}63.1 \\
(\mathrm{n}=198)\end{array}$ & $2.61(2.21-3.09)$ \\
\hline Yes, four times or more & 71.1 & $3.10(2.62-3.67)$ & 72.6 & $2.83(2.29-3.49)$ & 67.7 & $3.20(2.37-4.32)$ \\
\hline Victim of racket & $(n=34907)$ & $p<0.001^{*}$ & $(n=17146)$ & $p<0.001 *$ & $(n=17233)$ & $p<0.001^{*}$ \\
\hline No & $\begin{array}{c}43.8 \\
(\mathrm{n}=8349)\end{array}$ & 1.00 & $\begin{array}{c}47.9 \\
(n=4736)\end{array}$ & 1.00 & $\begin{array}{c}39.7 \\
(\mathrm{n}=3481)\end{array}$ & 1.00 \\
\hline Yes, once or sometimes & $\begin{array}{c}56.9 \\
(\mathrm{n}=1812)\end{array}$ & $1.69(1.61-1.78)$ & $\begin{array}{c}59.8 \\
(\mathrm{n}=1105)\end{array}$ & $1.62(1.52-1.73)$ & $\begin{array}{c}52.6 \\
(\mathrm{n}=664)\end{array}$ & $1.68(1.57-1.81)$ \\
\hline Yes, often or very often & 64.3 & $2.31(2.09-2.55)$ & 66.5 & $2.16(1.90-2.46)$ & 60.8 & $2.36(2.00-2.76)$ \\
\hline
\end{tabular}

(n) is the total number of subjects by categories, $\% \mathrm{I}^{+}$is the percentage of injuries and $*$ is a p value from a trend test 


\subsection{Multivariable Analyses}

Because of results from the univariate analyses, multivariate models were presented separately for boys and girls. The differences between the two models were, after adjustment by all variables included in the model, that the practice of exercise during free time, feelings of loneliness and perception of one's own health, remained significant for boys and not for girls. We also observed that tobacco consumption did not remain significantly associated both for boys and girls, that association with feelings about school, which was significant for boys (but not for girls) in univariate analyses, did not remain significantly associated and that, feelings of happiness, which was not significantly associated for girls (but was for boys) in univariate analyses, became significant in the multivariate model. Finally, after adjusting for all the independent variables remaining in the final model, some associations were weaker than those observed in univariate analyses both for boys and girls: age, truancy, being tired on waking up, fights, racket and bringing a weapon to school (Table 8)

Table 8. Adjusted odds ratio ( $95 \%$ IC) derived from the logistic regression

\begin{tabular}{|c|c|c|}
\hline & $\begin{array}{c}\text { Boys } \\
\left(\mathrm{n}=17527, \mathrm{I}^{+}=\right. \\
8988) \\
\text { H\&L: } \mathrm{p}=0.192 \\
\mathrm{p}-\mathrm{value} \\
\mathrm{OR}_{\mathrm{a}}(95 \% \mathrm{IC})\end{array}$ & $\begin{array}{c}\text { Girls } \\
\left(\mathrm{n}=16599, \mathrm{I}^{+}=\right. \\
6974) \\
\text { H\&L: } \mathrm{p}=0.751 \\
\mathrm{p}-\text { value } \\
\mathrm{OR}_{\mathrm{a}}(95 \% \mathrm{IC})\end{array}$ \\
\hline $\begin{array}{c}\text { Age (Years) } \\
9-11 \\
12-13 \\
14-15 \\
16-17 \\
18-25 \\
\end{array}$ & $\begin{array}{c}p<0.001 \\
1.55(1.38-1.74) \\
1.57(1.43-1.74) \\
1.46(1.33-1.60) \\
1.28(1.16-1.40) \\
1.00 \\
\end{array}$ & $\begin{array}{c}p<0.001 \\
1.90(1.69-2.14) \\
1.88(1.70-2.09) \\
1.63(1.48-1.80) \\
1.36(1.23-1.50) \\
1.00 \\
\end{array}$ \\
\hline $\begin{array}{c}\text { Tobacco } \\
\text { Never or try } \\
\text { Smoke } \\
\end{array}$ & $\begin{array}{c}p=0.956 \\
1.00 \\
0.99(0.84-1.18)\end{array}$ & $\begin{array}{c}p=0.943 \\
1.00 \\
1.01(0.69-1.49)\end{array}$ \\
\hline $\begin{array}{c}\text { Alcohol } \\
\text { Never or never being drunk } \\
\text { Being drunk } 1,2 \text { or } 3 \text { times } \\
\text { Being drunk } 4 \text { or more } \\
\text { times }\end{array}$ & $\begin{array}{c}p<0.001 \\
1.00 \\
1.28(1.19-1.38) \\
1.11(0.95-1.29)\end{array}$ & $\begin{array}{c}p<0.001 \\
1.00 \\
1.23(1.13-1.35) \\
1.07(0.76-1.52)\end{array}$ \\
\hline $\begin{array}{c}\text { Exercise during free time } \\
\geq 3 \mathrm{x} / \text { week } \\
2 \mathrm{x} / \text { week to }>1 \mathrm{x} / \text { month } \\
\text { Never }\end{array}$ & $\begin{array}{c}p=0.014 \\
1.21(1.06-1.36) \\
1.18(1.04-1.34) \\
1.00\end{array}$ & $\begin{array}{c}p=0.641 \\
0.99(0.92-1.15) \\
1.03(0.92-1.15) \\
1.00\end{array}$ \\
\hline $\begin{array}{c}\text { Feel about school } \\
\text { Like it a lot or a bit } \\
\text { Don't like very much or at } \\
\text { all }\end{array}$ & $\begin{array}{c}p=0.618 \\
1.00 \\
0.97(0.84-1.10)\end{array}$ & $\begin{array}{c}p=0.092 \\
1.00 \\
0.86(0.72-1.03)\end{array}$ \\
\hline $\begin{array}{c}\text { Truancy } \\
\text { Never } \\
\text { From time to time } \\
\text { More than time to time }\end{array}$ & $\begin{array}{c}p<0.001 \\
1.00 \\
1.25(1.12-1.39) \\
1.24(1.11-1.39) \\
\end{array}$ & $\begin{array}{c}p<0.001 \\
1.00 \\
1.11(0.97-1.28) \\
1.32(1.14-1.53)\end{array}$ \\
\hline $\begin{array}{c}\text { Feeling } \\
\text { Very happy or happy } \\
\text { Don't feel happy or at all }\end{array}$ & $\begin{array}{c}p=0.003 \\
1.00 \\
1.11(1.04-1.18)\end{array}$ & $\begin{array}{c}p=0.002 \\
1.00 \\
1.12(1.04-1.20)\end{array}$ \\
\hline $\begin{array}{c}\text { Feeling alone } \\
\text { Sometimes or never } \\
\text { Very often or quite often }\end{array}$ & $\begin{array}{c}p=0.005 \\
1.00 \\
1.11(1.03-1.19)\end{array}$ & $\begin{array}{c}p=0.105 \\
1.00 \\
1.06(0.98-1.15)\end{array}$ \\
\hline $\begin{array}{c}\text { Number of close friends } \\
\text { None }\end{array}$ & $\begin{array}{c}p=0.020 \\
1.00\end{array}$ & $\begin{array}{c}p=0.307 \\
1.00\end{array}$ \\
\hline
\end{tabular}

\begin{tabular}{|c|c|c|}
\hline $\begin{array}{c}\text { One or two } \\
\text { Three or more }\end{array}$ & $\begin{array}{l}1.06(0.95-1.19) \\
1.14(1.02-1.27) \\
\end{array}$ & $\begin{array}{l}1.08(0.98-1.19) \\
1.07(0.96-1.18)\end{array}$ \\
\hline $\begin{array}{c}\text { Kindness and helpfulness } \\
\text { of pupils } \\
\text { Never or rarely } \\
\text { Sometimes } \\
\text { Often or always }\end{array}$ & $\begin{array}{c}p=0.066 \\
1.10(1.00-1.20) \\
1.06(0.98-1.13) \\
1.00\end{array}$ & $\begin{array}{c}p<0.001 \\
1.11(1.00-1.21) \\
0.92(0.86-0.99) \\
1.00\end{array}$ \\
\hline $\begin{array}{c}\text { Talking with parents or } \\
\text { tutors } \\
\text { Never or rarely } \\
\text { Sometimes or always }\end{array}$ & $\begin{array}{c}p<0.001 \\
1.00 \\
1.16(1.09-1.23)\end{array}$ & $\begin{array}{c}p<0.001 \\
1.00 \\
1.12(1.05-1.20)\end{array}$ \\
\hline $\begin{array}{l}\text { Perception of one's own } \\
\text { health } \\
\text { Excellent or rather good } \\
\text { Nor good nor bad } \\
\text { Not so good or poor, bad }\end{array}$ & $\begin{array}{c}p=0.004 \\
0.88(0.81-0.97) \\
1.00 \\
0.99(0.89-1.10)\end{array}$ & $\begin{array}{c}p=0.288 \\
0.99(0.91-1.09) \\
1.00 \\
1.06(0.96-1.18)\end{array}$ \\
\hline $\begin{array}{l}\text { Feeling tired on waking up } \\
\text { Never, rarely or sometimes } \\
\text { One or more a week }\end{array}$ & $\begin{array}{c}p<0.001 \\
1.00 \\
1.25(1.13-1.38) \\
\end{array}$ & $\begin{array}{c}p=0.002 \\
1.00 \\
1.19(1.06-1.33)\end{array}$ \\
\hline $\begin{array}{c}\text { Fights } \\
\text { Never } \\
\text { One or two times } \\
\text { Three times or more }\end{array}$ & $\begin{array}{c}p<0.001 \\
1.00 \\
1.44(1.33-1.55) \\
1.68(1.51-1.88) \\
\end{array}$ & $\begin{array}{c}p<0.001 \\
1.00 \\
1.45(1.34-1.58) \\
1.63(1.42-1.88) \\
\end{array}$ \\
\hline $\begin{array}{c}\text { Taking a weapon at school } \\
\text { Don't have } \\
\text { Don't bring } \\
\text { Yes, one or three times } \\
\text { Yes, four times or more }\end{array}$ & $\begin{array}{c}p<0.001 \\
1.00 \\
1.25(1.16-1.36) \\
1.89(1.59-2.25) \\
1.56(1.21-2.02) \\
\end{array}$ & $\begin{array}{c}p<0.001 \\
1.00 \\
1.30(1.21-1.41) \\
1.98(1.61-2.43) \\
2.48(1.65-3.72) \\
\end{array}$ \\
\hline $\begin{array}{c}\text { Victim of racket } \\
\text { No } \\
\text { Yes, once or sometimes } \\
\text { Yes, often or very often }\end{array}$ & $\begin{array}{c}p<0.001 \\
1.00 \\
1.43(1.32-1.55) \\
1.73(1.49-2.02)\end{array}$ & $\begin{array}{c}p<0.001 \\
1.00 \\
1.48(1.35-1.61) \\
1.90(1.56-2.31)\end{array}$ \\
\hline
\end{tabular}

\section{Discussion}

As reports on epidemiology and patterns of injuries based on population survey data are rare for low-incomes countries and much rarer for Cameroon, the results of our study augment our knowledge about childhood injuries in low-incomes countries. Moreover, because of the lack of non-hospital data and more specifically the lack of school survey data and also because - despite the work of the WHO through its "Guidelines for conducting community surveys on injury and violence" [18] - there is no current standard or recommended set of injury-related questions criteria for population data survey (i.e. on injury definition, injury severity, place of occurrence, mechanisms or activity at the moment of the "accident"), comparisons of our results with literature are not easy to make [15].

Concerning the prevalence of injuries, $46.7 \%$ of students have reported having had at least one injury during the 12 months before the study. This proportion is nearly the same as the $42.2 \%$ found by Peltzer and Pengdip [23] in four Southeast Asian countries but is lower than the $65.8 \%$ found in Botswana in 2005 by Peltzer [25] or the $61.1 \%$ found in Djibouti in 2007 by Muula, Siziya and Rudatsikira [25] and higher than the $13.5 \%$ found by Zhou, Chen and Dong [26] in Shenzhen city of China and lower.

Almost all the studies - based on study population data or on hospital data - found statistically significant relationships between gender and occurrence of injuries, with a higher risk 
for male [1-15, 23-32]. This is also case in our study, with a greater proportion for boys than girls $(50.8 \%$ and $42.1 \%$ respectively). The types of injuries also vary according to gender. Our results show that approximately ten percent of injuries $(12.4 \%)$ occurred on the road or on the way to or from school and nearly fifty percent occurred at home $(34.5 \%)$ or at a sport field $(16.7 \%)$ with girls who being more frequently injured at home ( $43.6 \%$ vs. $27.6 \%$ for boys) while boys were more injured during sports $(22.5 \%$ vs. $9.1 \%$ for girls). We have also found that the proportion of home injuries decreased with age, while sports injuries increased with age. Peltzer and Pengpid [23] and Pickett, Molcho, Simpson, Janssen, Kuntsche, Mazur, Harel and Boyce [27], who assessed cross-sectional national data from the Global School-based Health Survey (in Indonesia, Myanmar, Sri Lanka and Thailand for Peltzer) and the Health Behavior in School-aged Children (from 35 middle and high-incomes countries for Pickett), also found more home injuries among girls ( $28.5 \%$ vs. $20.8 \%$ for boys) and more sports injuries among boys ( $25.0 \%$ vs. $15.5 \%$ for girls). The street, road or parking injuries occurred for around ten percent $(11.2 \%$ for boys and $10.2 \%$ for girls). The same tendencies were found by de souse Petersburgo and Keyes [28] with $68.1 \%$ of home injuries for girls (vs. 58.4\% for boys) and more injuries in "athletic / sporting facility" for boys (21.3\% vs. $2.1 \%$ for girls). At this point of the discussion, it is important to note that, road traffic injuries, which are the most reported and documented injuries in mortality statistics, and for which many prevention programs are being conducted, were not the major type of injuries found in our study. However, these injuries are also important because they can lead to truancy, with high care costs and disability for a short or a long term.

Regarding age of pupils, we found that the injury types change with age (with more home injuries for children and more sports injuries for adolescents) and that the proportions of injuries decreased with age. Some authors found opposite results: either an increase of injuries with age or no association with age $[9,13,24,28,29]$. One explanation could be that our study concerned morbidity of "minor" injuries while other studies, based on hospital-data, concerned more "severe injuries" (leading to emergency care). It is also known that "Adolescence, in particular, is an important period because it is the time when young people are experimenting with, and also establishing, their lifestyle, attitudes, concepts, beliefs and habits that may have long-term influences on their health" [24]; furthermore "engaging in one form of risk behavior may indicate an increased likelihood to engage in others" [30] like tobacco, alcohol and drugs consumption or violent behaviors.

Tobacco and alcohol consumption were analyzed in this study. Although proportions of injuries were higher for the smokers ( $56.0 \%$ vs $46.5 \%$ for non-smokers), this association was not significant. This may be because the proportion of smokers was quite low (7.7\%).Zhou, Chen and Dong [26]found a significantly higher proportion for students who had tried to smoke ( $17.1 \%$ vs 12.30 for those who have not) and a higher proportion of injuries for the students who declared alcohol consumption (15.3\% vs. $10.56 \%$ for those who do not drink). Also, in a study on gradients in risk for youth injury with multiple-risk behaviors, Pickett, Garner, Boyce and King [30] found more smokers (26.0\% vs. $17.1 \%)$ and more drinkers $(40.4 \%$ vs. $27.6 \%)$ among the injured group of adolescents. The same tendencies were found by Peltzer [24] in Botswana and by Peltzer and Pengpid [23] in four Southeast Asian Countries. In our results, alcohol consumption was associated with injuries both for boys and girls, but we did not observe a gradient association, maybe because only $3 \%$ of the youngsters reported to have been drunk 4 times or more.

The proportions of injuries were higher for boys who reported to have three or more close friends. Picket and colleagues also found such relations [30, 32]. One explanation can be that the (risk) behaviors do not occur in isolation and are often associated with peer group activities. On the other hand, absence of close friends and feelings of loneliness may also be associated factors of injuries. Peltzer and Pengpid [23] found that a greater psychological distress was associated with injury prevalence. We found associations between injuries and happiness, loneliness (but only for boys) and kindness and helpfulness of others pupils (but only for girls); and also weaker associations with the perception on health, which can be interpreted as psychosomatic symptoms of "not being happy". These associations on the one hand, between injuries and close friends, and on the other hand, between injuries and "psychological distress", are interesting because it's not because the youngsters have some close friends that they can't be feel alone or unhappy. These finding lead to the necessity of having another study, specifically on "mental health and well-being" for more investigate the relations between these associated factors and the self-inflicted injuries and suicidal behaviors, for example.

Concerning "violent behaviors", all authors found, on the one hand, an association between fighting, bullying and weapon carrying, and on the other hand, between these violent-related behaviors and injuries [24-26, 30, 31, 33]. Nearly one-third $(30.3 \%)$ of the youngsters included in our study declared at least one fight within the last twelve months with more boys than girls doing so. Muula, Siziya and Rudatsikira[25] found that $57.6 \%$ of their sample was involved in a physical fight, and $42.1 \%$ was bullied one time or more; they also found that the proportion of injuries was higher for those who reported fights (701\% vs. $47.5 \%$ ). In the Zhou, Chen and Dong study [26], the proportion of injuries was $24.68 \%$ for those who have reported physical fights whit $10.95 \%$ for the others. In our multivariable analyses, the associations between injuries and violent behaviors were the strongest. We found that boys more than girls declared having fought with close friends or friends and more girls than boys to have fought with brothers or sisters. Boys also reported more fights with unknown people. In their study on violence-related behaviors as associated factors of injuries, Pickett, Craig, Harel, Cunningham, Simpson, Molcho, Mazur, Dostaler, Overpeck and Currie 
[30] also found that "differences observed in the context of physical fights by gender suggest that girls most likely to fight with intimate relationships. Although boys also fight in such contexts, they are much more likely to fights with total strangers. This finding may reflect boy's extrinsic tendencies to engage in group and community activities". Smith-Khuri, Iachan, Scheidt, Overpeck, Gabhainn, Pickett and Harel [33] found that a large proportion of adolescents who fought, were also reporting bullying others and vice versa. These authors also found that the fighting prevalence increased with the use of alcohol, tobacco and decrease as children reported liking school more. All these results are in favor of the theory of the "multiple risk behavior" $[14,16,23$, 32-33].

This study has some limitations: the cross sectional study design precludes any determination of the direction of causality. Moreover, it was study with a general approach based on the reporting of health behaviors in school-aged children, so it is possible that some young people have not or under reported either intentionally or inadvertently on any of the questions asked. The intentionality was probably minimized by the fact that it was an auto-administered questionnaire. But for the report of injuries, the 12 months recall may also lead to an underestimation of injuries because of the "less serious" - those who did not result in a care - can be forgotten $[15,17,23,34]$. Finally, only the pupils at school at the moment of the study have participated, we may be missed young people most at risk. It's a possible bias knowing that the United Nations Children's Fund report that, although the school is compulsory, only $82 \%$ of boys and $77 \%$ of girls actually attend school [35].

\section{Conclusion}

Our work have shown that approximately half of the school-aged Cameroonian children included in this analyze reported having been injured at least once during the 12 months before the study, with a higher proportion among boys than girls. We also noted that, road traffic injuries, which are the most reported and documented injuries in mortality statistics, and for which many prevention programs are leading, were not the major type of injuries found in our study: it was the home and sports injuries that it was the most reported. About the inconvenience caused by the injury, slightly more than half of the youngsters have reported having missing school at least one day because of their injury, with $25 \%$ of them having had more than 7 missing school days. This information gives us an approximation of the injury severity.

Concerning the risk factors associated to injury, we have identified alcohol consumption, exercise performed during free time, truancy, happiness, feeling alone, number of close friends, feeling of kindness and helpfulness by the other pupils, possibility to talk with parents or tutors, self-perceived health, feeling tired on the morning of schooldays, and some indicators of violent behaviors (fights, number of times students reported taking a weapon at school and racket events) as associated factors with some variations according to gender. Some authors have reported that "one of the most commonly cited approaches to the prevention of childhood injuries is the targeting of interventions toward subgroups at highest risk" [31].Some of our results showed that a large part of the identified risk factors are common with other health risk behaviors, so our results correlates with literature, have implications for prevention programs. They objectify that is clearly necessary to have an overall approach of the youngsters and their lifestyles, both based on the prevention of risk factors but also on the strengthening of protective factors.

\section{Acknowledgements}

The study was under the responsibility of C. Mbena (Ministry of secondary education, Cameroon) and of D. Piette, G Houioux\& P. de Smet (ULB, Belgium). MP.Kuate (Ministry of primary education, Cameroon) and P. Libite (Cameroon's National Institute of Statistics) were very active respectively during the preparation of the survey and the data processing. The project was financed by the World Bank via Plan Cameroon, the "PASE" (Mr Tchameni, "Plan d'Appui au Système Educatif'), and finally Education Management Europe (Serge Coussement) who sub-contracted the project to the ULB.

\section{REFERENCES}

[1] World Health Organization and United Nations Children's Fund. World Report on Child Injury Prevention. The World Health Organization, Geneva, 2008.

[2] Hofman K, Primack A, Keuch G, Hrynkow S. Adressing the growing burden of trauma and injury in low- and middle-income countries. Am J Public Health 2005; 95:13-7.

[3] Otieno T, Woodfield JC, Bird P, Hill AG. Trauma in rural Kenya. Injury, Int. J. Care Injured 2004; 35:1228-1233.

[4] Juillard C, EtouniMballa GA, BiloungaNdongo C, Stevens K, Hyder A. Patterns of Injury and Violence in Yaoundé Cameroon: An Analysis of Hospital Data. World J Surg 2011; 35:1-8.

[5] Howe LD, Huttly RA, Abramsky T. Risk factors for injuries in young children in four developing countries: the Young Lives Study. Trop Med Int Health 2006; 11:1557-1566.

[6] NSekeroE, Curationis M, Brysiewicz P. Injury Surveillance in a Central Hospital in Kigali, Rwanda. J Emerg Nurs 2010; 36:212-216.

[7] OsifoOD, Ehiawaguan Iribhogbe P, Enoghama Ugiagbe E. Epidemiology and pattern of paediatric and adolescent trauma deaths in a level 1 trauma center in Benin city, Nigeria. Injury, Int. J. Care Injured 2012; 43:1861-1864. 
[8] ChicomMefire A, EtouniMballa GA, AzabijKenfack M, Juillard C, Stevens K. Hospital-based injury data from level III institution in Cameroon: Retrospective analysis of the present registration system 2013. Injury, Int. J. Care Injured 2013; 44:139-143.

[9] Zwi KJ, Zwi AB, Smettanikov E, Söderlund N, Logan S. Patterns of injury in children and adolescents presenting to a South African township health center. InjPrev1995; 1:26-30.

[10] Kobusingye OC, Lett RR. Hospital-Based Trauma Registries in Uganda. J Trauma 2000; 48:498-502.

[11] Kanchan T, Menezes RG, Monteiro FNP. Fatal unintentional injuries among young children - A hospital based retrospective analysis. J Forensic Leg Med 2009; 16:307-311.

[12] Patton GC, Coffey C, Sawyer SM, Viner RM, Dagmar MH, Bose K, Vos T, Ferguson J, MathersC.Global patterns of mortality in young people: a systematic analysis of population health data. Lancet 2009; 374:881-892.

[13] Viner RM, Coffey C, Mathers C, Bloem P, Costello A, Santelli J, Patton GC. 50-year mortality trends in children and young people: a study of 50 low-income, middle-income, and high-income Lancet 2011; 377:1162-1174.

[14] Pattussi MP, Lalloo R, Bassani DG, Olinto MTA. The role of psychosocial, behavioural and emotional factors on self-reported major injuries in Brazilian adolescents: A case-control study. Injury, Int. J. Care Injured 2008; 39:561-569.

[15] Heinen M, McGee KS, Warner M. Injury questions on houselhodsurveys from around the world. InjPrev 2004; 10:327-329.

[16] Chapman RL, Buckley L, Sheehan MC, Shochet IM, Romaniuk M. The impact of school connectedness on violent behavior, transport risk-taking behavior, and associated injuries in adolescence. J SchPsychol 2011; 49:399-410.

[17] Li G, Baker SP. Injury research. Theories, Methods and Approaches. Springer, New York, 2012.

[18] World Health Organization. Guidelines for conducting community surveys on injuries and violence. The World Health Organization, Geneva, 2004.

[19] Piette D, Houioux G, De Smet, P, Mbena C. Démarche participative d'une étude de la santé des jeunes d'âge scolaire au Cameroun. IUHPE world Conference on Health Promotion and Education, Geneva, 2010.

[20] Health Behavior in School-aged Children. Online Available from http://www.hbsc.org

[21] Institut National de la Statistique (INS) and ORC Macro. 2004. Enquête Démographique et de Santé du Cameroun 2004. Calverton, Maryland, USA : INS et ORC Macro. Online Availablefromwww.measuredhs.com

[22] Hosmer DW, Lemeshow S. Applied Logistic Regression.
Second Edition. Wiley Series in Probability and Statistics. Wiley, New-York, 2000

[23] Peltzer K, Pengpid S. Injury and Social Correlates among in-School Adolescents in Four Southeast Asian Countries. Int J. Environ Res Public health 2012; 9:2851-2862.

[24] Peltzer K. Prevalence and social correlates of injury among in-school adolescents in BotswanaAfrican Safety Promotion: A Journal of Injury \& Violence Prevention 2009; original contribution.

[25] Muula AS, Siziya S, Rudatsikira E. Prevalence and socio-demographic correlates for serious injury among adolescents participating in the Djibouti 2007 Global School-based Health Survey. BMC Research Notes 2011; $4: 372$.

[26] Zhou L, Chen D, Dong G. Characteristics and related factors of nonfatal injuries among adolescents and college students in Shenzhen city of China. BMC Public Health 2013; 13:392.

[27] Pickett W, Molcho M, Simpson K, Janssen J, Kuntsche E, J Mazur J, Harel Y, Boyce W. Cross national study of injury and social determinants in adolescents.Inj Prev. 2005; 11: 213-218.

[28] desousaPetersburgo D, Keyes CE, The epidemiology of childhood injury in Maputao, Mozambique. Int J Emerg Med 2010; 3:157-163.

[29] Robsertson L. Injury Epidemiology. Oxford University Press, Oxford, 1992.

[30] Pickett W, Craig W, Harel Y, Cunningham J, Simpson K, Molcho M, Mazur J, Dostaler S, Overpeck MD, Currie CE; HBSC Violence and Injuries Writing Group. Cross-national study of fighting and weapon carrying as determinants of adolescent injury. Pediatrics 2005; 116:855-863.

[31] Pickett W, Garner MJ, Boyce WF, King MA. Gradients in risk for youth injury associated with multiple-risk behaviours: a study of 11,329 Canadian adolescents. SocSci Med 2002; 55:1055-1068.

[32] Pickett W, Schmid H, Boyce WF, Simpson K, Scheidt PC, Mazur J, Molcho M, King MA, Godeau E, Overpeck M, Aszmann A, Szabo M, Harel Y. Multiple risk behavior and injury: an international analysis of young people. Arch PediatrAdolesc Med 2002; 156:786-93.

[33] Smith-Khuri E., Iachan R, Scheidt PC, Overpeck MD, Gabhainn SN, Pickett W, Harel Y. A Cross-national Study of Violence-Related Behaviors in Adolescents. Arch PediatrAdolesc Med 2004; 158: 539-544.

[34] Mock C, Acheampong F, Adjei S, Koepsell T. The effect of recall on estimation of incidence rates for injury in Ghana. IntJ Epidemiol. 1999; 28(4):750-755

[35] UNICEF. Cameroonian Demographics Statistics. Online Available from http://www.unicef.org/ 